\title{
First record of Macrostemum alienum Ulmer 1907 (Trichoptera: Hydropsychidae: Macronematinae) from Ile-Ife, Southwestern Nigeria, West Africa
}

\author{
Sylvester Sunday Ogbogu ${ }^{1}$ and Williams Babasola Adu ${ }^{2}$
}

Biota Neotropica v6 (n3) -http://www.biotaneotropica.org.br/v6n3/pt/abstract?short-communication+bn00606032006

Date Received 08/01/2005

Revised 07/08/2006

Accepted 09/01/2006

1. Department of Zoology, Obafemi Awolowo University Ile - Ife 220005, Osun State, Nigeria.

E-mail:slyd58@yahoo.com

2. Department of Integrated Science, Adeyemi College of Education Ondo, Ondo State, Nigeria.

E-mail: williamsadubabs@yahoo.com

Correspondence author: S.S. Ogbogu, Department of Zoology, Obafemi Awolowo University Ile - Ife 220005, Osun State, Nigeria. E-mail: slyd58@yahoo.com

\begin{abstract}
Ogbogu, S.S. and Adu, W.B. First record of Macrostemum alienum Ulmer 1907 (Trichoptera: Hydropsychidae: Macronematinae) from Ile-Ife, Southwestern Nigeria, West Africa. Biota Neotrop. Sep/Dez 2006 vol. 6, no. 3 http:// www.biotaneotropica.org.br/v6n3/pt/abstract?short-communication+bn00606032006ISSN 1676-0611
\end{abstract}

Macrostemum alienum Ulmer, 1907, was collected in Ile-Ife, Southwestern Nigeria and is reported for the first time. The implication of this as regards the geographical distribution of this species is discussed.

Key words: Macrostemum alienum, larva, Trichoptera Hydropsychidae, Macronematinae, Nigeria, West Africa

\section{Resumo}

Ogbogu, S.S. and Adu, W.B. Primeiro registro de Macrostemum alienum Ulmer 1907 (Trichoptera: Hydropsychidae: Macronematinae) em Ile-Ife, sudoeste da Nigeria, West Africa. Biota Neotrop. Sep/Dez 2006 vol. 6, no. 3 http:// www.biotaneotropica.org.br/v6n3/pt/abstract?short-communication+bn00606032006ISSN ISSN 1676-0603

Macrostemum alienum Ulmer, 1907, foi coletado e teve sua ocorrência registrada pela primeira vez em Ile-Ife, no sudoeste da Nigéria. As implicações deste registro para as discussões referentes à distribuição geográfica desta espécie são apresentadas.

Palavras-chave: Macrostemum alienum, larva, Trichoptera Hydropsychidae, Macronematinae, Nigeria, West Africa

http://www.biotaneotropica.org.br 


\section{Introduction}

There has been copious documentation of the caddisfly family Hydropsychidae from the Afrotropical region (Kimmins 1960, 1962, Gibbs 1973, Barnard 1980, 1984, Scott 1983, Andersen \& Johanson 1992, Johanson 1992, Gibon et al. 1994). The family is diverse and widely distributed; hence many species have been described and it is believed that more species are still unknown (Scott 1983, Johanson 1992, Morse 1997). In the faunal list of East African caddisflies in Johanson (1992), Hydropsychidae ranks second to the Leptoceridae in having the highest number of genera and species. Up to 102 species are known worldwide (Morse 1999).

Earlier reports on hydropsychid caddisflies in the Afrotropical region were mainly from East, Central and Southern Africa (Scott 1988, Anderson \& Johanson 1992) with a few from West Africa (Petr 1970, Gibbs 1973, Hynes 1975). However, there have been a number of recent reports from West Africa (Marlier 1978, Statzner 1984, Statzner \& Gibon 1984, Statzner et al. 1985, 1987 Gibon et al. 1994, Kjaerandsen \& Andersen1997, Andersen \& Kjaerandsen 2001), but they are from just a few countries in the sub-region. Therefore, as pointed out in Andersen \& Kjaerandsen (2001) and Kjaerandsen (2005), it is evident that the hydropsychid caddisfly fauna of the rest of the West-African sub-region is not completely known. Furthermore, many described species also need redescription to allow for clear, precise recognition (Kjaerandsen 2005). For example, there is a dearth of information pertaining to the caddisfly fauna in Nigeria compared to those in other West African countries, such as Ghana (Gibbs 1973, Kjaerandsen \& Andersen 1997) and Ivory Coast (Statzner 1982, 1984), where extensive studies have been carried out. The first documented study of hydropsychid caddisflies in Nigeria is in the author's earlier paper (Ogbogu 2001) in which larvae were observed in a reservoir spillway.

Kimmins $(1962,1963)$ described many African species of the macronematine Amphipsyche McLachlan. Since then, as noted by Barnard (1984), new characters have been discovered in some of the species. Barnard (1984) provided keys to only the adults of Afrotropical and Old World species of Amphipsyche. In addition, Statzner \& Gibon (1984) described a new species each for Leptonema GuerinMeneville and Protomacronema Ulmer and gave keys to the adults and larvae of the species of Polymorphanisus Walker, Aethaloptera Brauer, Leptonema, Protomacronema, Amphipsyche and Macrostemum Kolenati. Macrostemum is a large genus with 95 species that are known worldwide (ITIS 2004). Up to 15 species exist in the Neotropical region (Flint \& Bueno-Soria 1982, Flint et al 1999) and over 20 species are known from the Afrotropical region (Scott1983, Statzner \& Gibon 1984). Of these, five species (M. alienum Ulmer, $M$. capense Walker, $M$. distinctum Ulmer, $M$. inscriptum Walker and an unidentified Macrostemum spe- cies) have been reported from West Africa (Marlier 1978, Scott 1983, Statzner \& Gibon 1984, Johanson 1992). The first report of Macrostemum alienum Ulmer in the Afrotropical region is that of Ulmer (1907), based on materials from Sudan and Ghana. Further studies have also recorded M. alienum in some parts of West Africa - including those of Statzner \& Gibon (1984) from Ivory Coast, and Kjaerandsen \& Andersen (1997) from Ghana. There has been no documented report of $M$. alienum in Nigeria.

Detailed knowledge of the Macrostemum species found in Nigeria is therefore crucial, especially if studies involving hydropsychid caddisflies are to be carried out with confidence. Apart from providing more information on the geographical distribution of the species, the threatened status of the lowland rainforests in West Africa (Sayer et al. 1992, Chatelain et al. 1996) makes this study imperative and urgent.

The aim of this paper is to report for the first time the occurrence of $M$. alienum around an impoundment in IleIfe, located in a tropical rainforest zone of southwestern Nigeria. The implication of this report for knowledge of the geographical distribution of $M$. alienum is discussed.

\section{Materials and Methods}

More than 20 mature larvae were collected by one of the authors (WBA) below the spillway of Opa reservoir in Ile-Ife (lat. $07^{\circ} 302 \mathrm{~N}$; long. 04 342 E) (9.xii.2004) and taken to the laboratory in $70 \%$ ethanol. They were first examined in glycerin under the binocular microscope for preliminary identification (i.e. to family and generic levels) using the keys in Scott (1983) and Statzner \& Gibon (1984). The head of a larva was removed and dehydrated in alcohol after boiling in dilute $\mathrm{KOH}$ and washing, cleared in xylene and fixed on a microscope slide with Canada balsam. The head capsule; the nota; the fore-, mid- and hindlegs and the anal prolegs of the larva were also dissected out, prepared with the same method and mounted on slides. Photographs of these body parts, highlighting important morphological features, were taken with a 35mm PM6 camera attached to an Olympus BH microscope. To identify the specimen to species level, the illustrations and keys in Statzner \& Gibon (1984) were used.

\section{Results}

\section{Diagnosis}

The larva of $M$. alienum can be confused with those of other Macrostemum species, but is easily separated by looking at the nature of the anterior margin of the prosternal plate and the intersegmental sclerites associated with it. The prosternal plate has a ridge at the middle of the anterior margin, which is almost divided by a suture. The carina at the dorsal side of head cuts off a triangular portion at the 

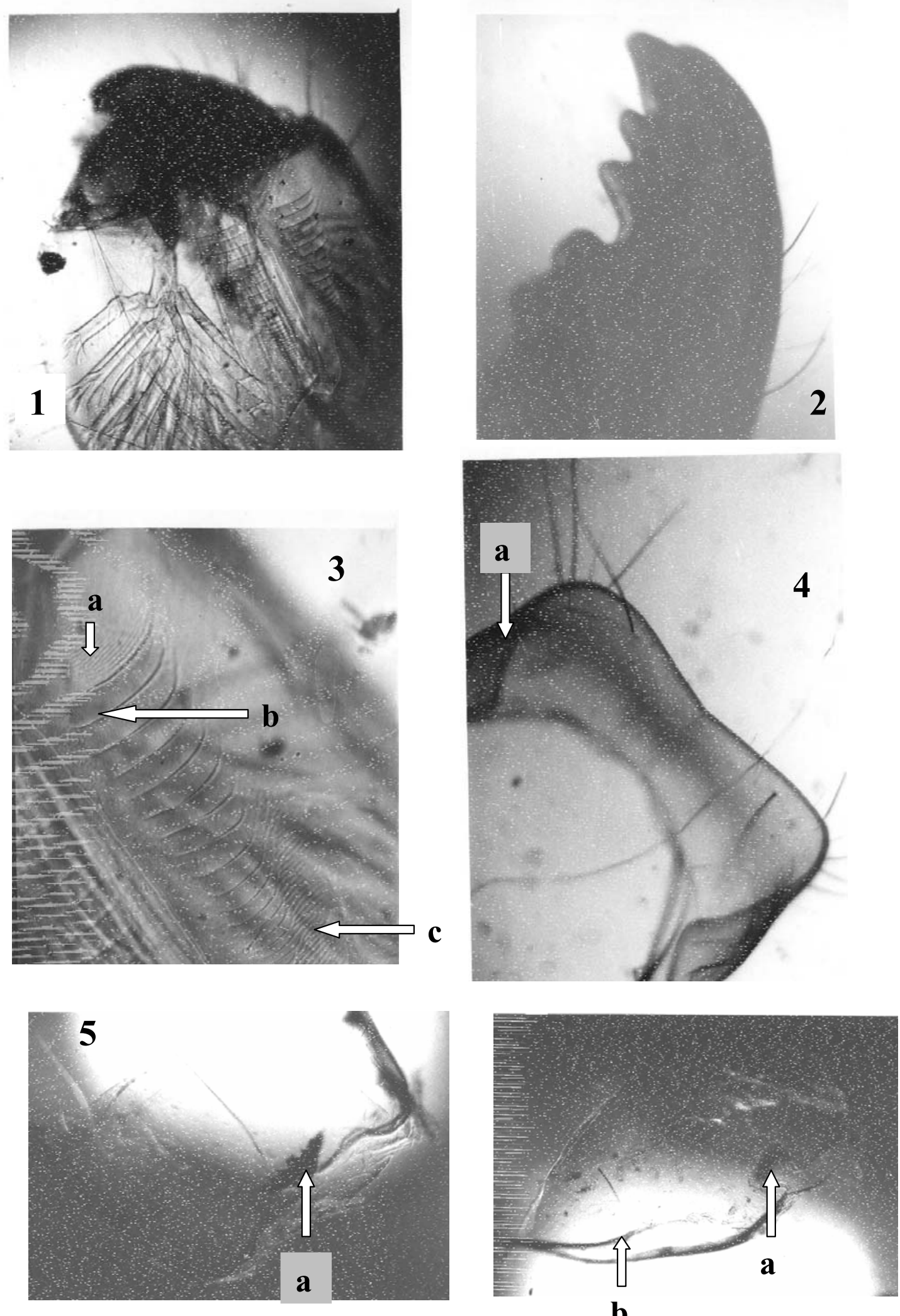

Figures 1-6: Larva, Macrostemum alienum. 1,-Head, dorsal view. 2.-Left mandible, dorsal view. 3.-Head, at increased magnification to show stridulatory ridges, ventral view. 4.-Pronotum showing (a) antero-lateral corner, dorsal view. 5.-Lower part of mesonotum showing posterior margin with (a) crescent-shaped black marking. 6.-Left side of metanotum showing (a) round black marking at the posterior margin and (b) a diagonal strip.

http://www.biotaneotropica.org.br 

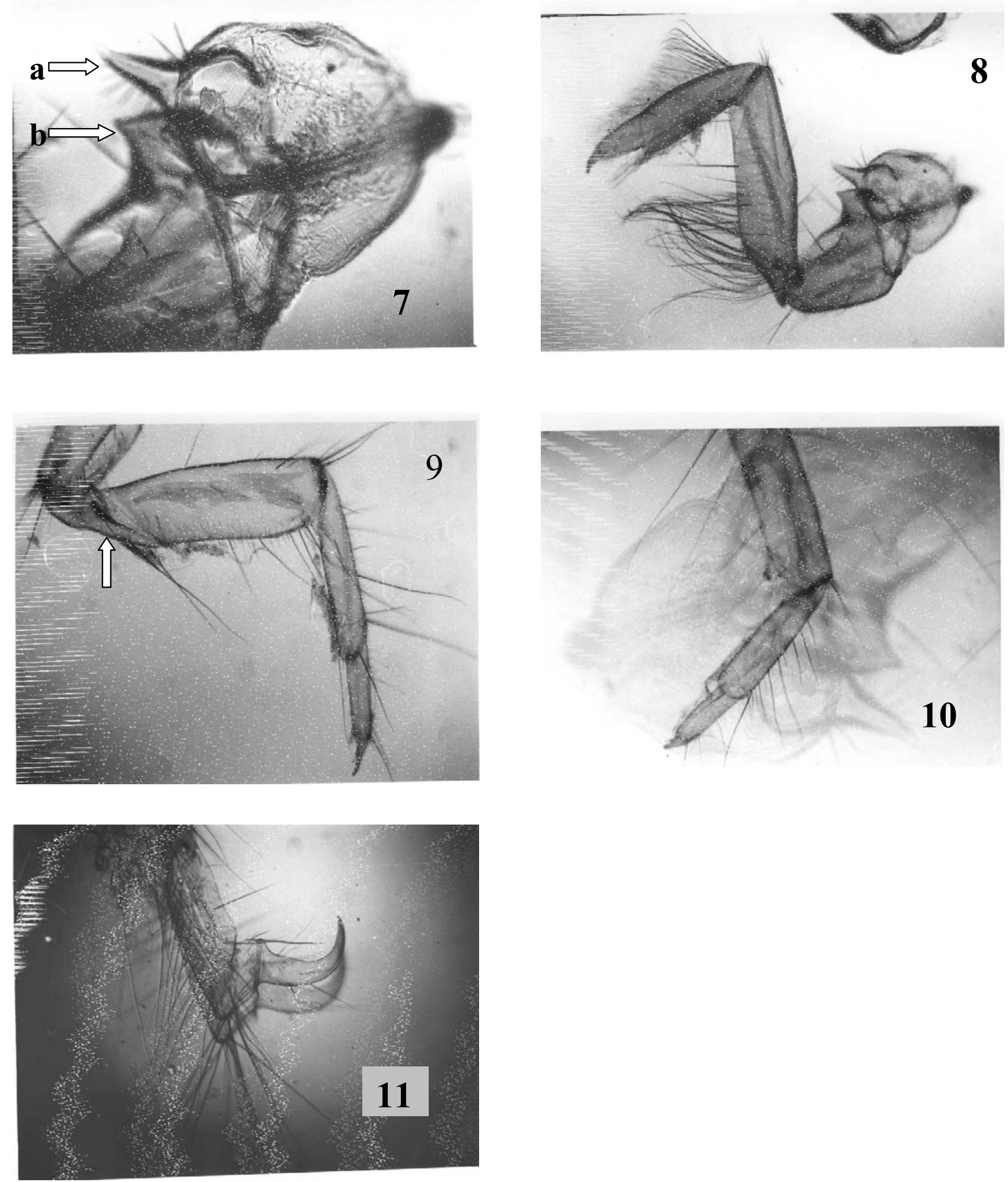

Figures 7-11: Larvae, Macrostemum alienum. 7.-Forecoxa, at increased magnification to show (a) foretrochantin, dorsal view. 8.-Right foreleg dorsal view. 9.-Midleg. Arrow points to the trochanter. 10.-Hindleg femur and tarsus. 11.-Anal proleg and claw, lateral view. 
apex of the frontoclypeal apotome. In addition, as illustrated in Statzner \& Gibon (1984), the stridulatory ridges exhibit two distinct patterns of arrangement. The proximal, finer, closely spaced ridges (fig. 3a) are followed by coarse ones in the middle (fig. 3b). In turn, these are followed by the finer ridges distally (fig. 3c). This is the most reliable character for diagnosis M. alienum larva. Specimens (in alcohol) have been deposited in the Natural History Museum (NHM) in Obafemi Awolowo University, Ile-Ife, Nigeria.

\section{Description}

Entire length and head width of larva average $25 \mathrm{~mm}$ and $2.3 \mathrm{~mm}$ respectively. Dorsal area of head brown with a ridge (carina), which cuts off a small distal portion of frontoclypeal apotome. Abdominal gills highly branched throughout the stem.

Head: Eyes small, black and located anteriorly in a pale white area; mandibles broad, projecting forward (fig. 1) and heavily sclerotized; the left mandible with three apical teeth and two lateral stout teeth (fig. 2); transverse stridulatory ridges very fine anteriorly and wider apart (coarse) in the middle and again finer at the distal part (fig 3a, b \& c).

Thorax: Thoracic segments short; pronotum brownish with a median suture, anterior and posterior margin slightly dark, lateral margin with dark thickening mostly at the antero-lateral corners (fig 4a); meso- and metanota brownish and dark at the lateral margins, without median suture but with crescent-shaped and round black marks at the middle of posterior margins respectively (figs. 5a \& 6a); two diagonal stripes run across the shield in metanotum (fig. 6b); prosternal plate partly divided by a suture originating from the apex of the ridge formed by the anterior margin (fig. 5); one pair of highly branched mesosternal gills and two pairs at the metasternum.

Legs: All legs brownish; foretrochantin not forked, pointed and bears setae (fig. 7a); foreleg coxa with a triangular process at the anterior region below the foretrochantin (fig. 7b), foreleg tibia, tarsus and distal margin of femur with dense long hairs (fig. 8); proximal region of trochanter narrower than distal region (fig. 9); tarsus bears a single claw and a short stout basal spine (fig. 10).

Abdomen: Abdomen with rows of highly branched gills on ventral and ventro-lateral sides; anal proleg ending in a well-developed, long curved anal claw (fig. 11).

\section{Discussion}

The Macrostemum larva examined in this study keys to Macrostemum alienum using Statzner (1984). It is also very similar to the material illustrated by Statzner (1984). In discussing the distribution of macronematine caddsiflies in Ivory Coast, Statzner \& Gibon (1984) noted that
Macrostemum is widely distributed and that species of the genus are restricted somewhat to the various regions of the country. In that report, $M$. alienum distribution cuts across almost the entire non-mountainous parts of the country but occurs more in the transition zone between the northern 'dry' savannah and southern lowland forest regions (see fig. 19 in Statzner \& Gibon 1984). Current velocity and length of dry period in streams were identified as factors influencing the distribution. Reporting on the Ghana fauna, Kjaerandsen \& Anderson (1987) also associated M. alienum with the eastern region of the country, which is most similar to the topography and vegetation of the transition zone in Ivory Coast. In the present study, however, material was collected below a dam where water current is usually high during the rainy season and Ile-Ife is located in a tropical rainforest region, which is wetter than the adjacent savannah region towards northern Nigeria. Also, in the biogeographical regions outlined in Kjaerandsen \& Andersen (1997), M. alienum occurs in the Ashanti region of Ghana as well as Eburneo-Ghanean and Sudaninan regions of West Africa. The ability of $M$. alienum to occur in varying vegetation zones suggests that the species is probably highly plastic and as such may be as widely distributed as $M$. capense Walker, as noted in Scott (1983).

To conclude, it has been established that M. alienum is present in Ile-Ife, Nigeria, indicating that its distribution range is beyond what is known from previous studies. Previous reports on distribution were based on materials collected from larger rivers, but reports have shown that small streams that maintain almost steady flow year round also are inhabited by the hydropsychid caddisfly species. Further sampling of streams is needed, particularly in the rainforest regions of West Africa, in which greater number of species may be found and where the forests are quickly disappearing. This would be helpful in determining the actual distribution ranges of caddisflies species in the West-African subregion in particular, and in the Afrotropical region in general.

\section{Acknowledgements}

We are indebted to T. Andersen, J. Kjaerandsen, B. Statzner and P.C. Barnard, who were helpful with the reprints of their publications, some of which were used during the study. We acknowledge the contributions made by J.O. Jegede and J. Oyebanji who helped with the photographs, and O. Osoniyi who assisted in the organization of the photographs in the text. C. O. Ogbogu was also helpful in reading through the final draft of the manuscript. We also acknowledge the criticisms and suggestions made by the two reviewers, which improved the quality of the manuscript. 


\section{References}

Andersen, T. \& Johanson, K.A. 1992. Caddisflies (Trichoptera) from a mountain rain forest in N.E. Tanzania. Proceedings of the $7^{\text {th }}$ International Symposium on Trichoptera, 1992. 59-64.

Andersen, T. \& Kjaerandsen, J. 2001. Adult caddisfly diversity along a headwater stream in southeastern Ghana (Insecta: Trichoptera) Verh. - Int. Ver. Theor. Angew. Limnol. 27: 3613-3618.

Barnard, P.C. 1980. A revision of the Old World Polymorphanisini (Trichoptera: Hydropsychidae). Bull. Br. Mus. (Nat. Hist.) Entomol. 4(2) 59-106.

Barnard, P.C. 1984. Macronematine caddisflies of the genus Amphipsyche (Trichoptera: Hydropsychidae). Bull. Br. Mus. (Nat. Hist.) Entomol. 48(2):71-130.

Chatelain, C., Gautier, L. \& Spichiger, R. 1996. A recent history of forest fragmentation in southwestern Ivory Coast. Biodivers. Conserv. 5: 37-53.

Flint, O.S. Jr, \& Bueno-Soria, J. 1982. Studies of Neotropical caddisflies, XXXII: the immature stages of Macronema variipenne Flint \& Bueno, with the division of Macronema by the resurrection of Macrostemum (Trichoptera: Hydropsychidae). Proceedings of the Biological Society of Washington, 95(2): 358-370.

Flint, O.S. Jr., Holzenthal, R.W., and Harris, S.C. 1999. Catalog of the Neotropical Caddisflies (Insecta: Trichoptera) Ohio Biological Survey, Columbus, Ohio. iv + 239p.

Gibbs, D.G. 1973. The Trichoptera of Ghana. Deut. Entomol. Z. 20:363-424.

Gibon, F.-M., Guenda, W. \& Coulibaly, B. 1994. Observations sur la zonation des cours deau de la savane ouestafricaine: Trichptere du Sud-Ouest du Burkina Faso. Ann. Limnol. Station Biologique dulac d’Oredon, Faculte des Sciences de Toulouse. 30: 101-121.

Hynes, J.D. 1975. Annual cycles of macroinvertebrates of a river in southern Ghana. Freshw. Biol. 5: 71-83.

ITIS, 2004. Integrated Taxonomic Information System standard report page. http://www.itis.usda.gov/index.html (last visited 23/Nov/2004).

Johanson, K.A. 1992. A catalogue of the caddis flies of East Africa (Insecta, Trichoptera). Steenstrupia, 18(9): 113-141.

Kjaerandsen, J. 2005. Species assemblages and community structure of adult caddisflies along a headwater stream in southeastern Ghana (Insecta: Trichoptera). Biodivers. Conserv. 14:1-43.

Kjaerandsen J. \& Andersen, T. 1997. Preliminary checklist of the caddisflies (Trichoptera) of Ghana, West-Africa. pp. 239-247 In: Holzenthal R., \& O.S. Flint (eds). Proceedings of the $8^{\text {th }}$ International Symposium on Trichoptera, Ohio Biological Survey. Columbus, Ohio.
Kimmins, D.E. 1960. A review of the African species of the genus Cheumatopsyche (Trichoptera: Hydropsychidae), with special reference to those of Southern Africa. Bull. Br. Mus. (Nat. Hist.) Entomol. 9: 255-267.

Kimmins, D.E. 1962. New African caddis-flies (Order Trichoptera). Bull. Br. Mus. (Nat. Hist.) Entomol.12:81-121.

Kimmins, D.E. 1963. On the Trichoptera of Ethiopia.. Bull. Br. Mus. (Nat. Hist.) Entomol. 9: 255-267.

Marlier, G. 1978. Sur une collection de Trichopteres de l'Afrique occidentale. Rev. Zool. Africain 92: 283-301.

Morse, J.C. 1997. Checklist of World Trichoptera. pp. 339342. In. Holzenthal, R., \& O.S. Flint (eds.) Proceedings of the $8^{\text {th }}$ International Symposium on Trichoptera. Ohio Biological Survey, Colombus Ohio.

Morse, J.C. 1999. Trichoptera World Checklist. Available at http://entweb.clemson.edu/database/trichopt/index.htm (last visited 29/Apr/2006).

Ogbogu, S.S. 2001. Observations on the seasonal dynamics of caddisfly larvae (Trichoptera) in an intermittent reservoir outflow at Ile-Ife, Nigeria. J. Aquat. Sci. 16(2): 139-143.

Petr.T. 1970. The bottom fauna of the rapids of the Black Volta River in Ghana. Hydrobiologia, 36: 399-418.

Sayer, J.A., C.S. Harcourt \& M.N. Collins. 1992. The Conservation Atlas of Tropical Forests: Africa. International Union of Conservation of Nature and Natural Resources, Geneva, Switzerland.

Scott, K.M.F. 1983. On the Hydropsychidae (Trichoptera) of South Africa with keys to African genera of imagos, larvae and pupae and species list. Annals of the Cape Provincial Museums (Nat. Hist.), 14(8): 299-422.

Scott, K.M.F. 1988. Twenty-five years of Trichoptera research relating to Southern Africa - a personal view. J. Limnol. Soc. S. Afr. 14:16-23.

Statzner, B. 1982. Population dynamics of Hydropsychidae (Insecta: Trichoptera) in N'Zi River (Ivory Coast), a temporary stream partly treated with the insecticide chlorphoxin. Rev. Hydrobiol. Trop. 15: 157-176.

Statzner, B. 1984. Keys to adult and immature Hydropsychinae in the Ivory Coast (West Africa) with note on their taxonomy and distribution (Insecta: Trichoptera). Spixiana, 7:23-50.

Statzner, B. \& Gibon, F.M. 1984. Keys to adult and immature Macronematinae (Insecta: Trichoptera) in the Ivory Coast (West Africa) with notes on their taxonomy and distribution. Rev. Hydrobiol. Trop.17:129-151.

Statzner, B., Dejoux, C. \& Elouard, J. -M. 1985. Field experiments on the relationship between drift and benthic densities of aquatic insects in tropical streams (Ivory Coast). II. Cheumatocpsyche falcifera (Trichoptera: Hydropsychidae). J. Anim. Ecol. 55: 93-110. 
Ogbogu, S.S. and Adu, W.B. - Biota Neotropica, v6 (n3) - bn00606032006

Statzner, B., Dejoux, C. \& Elouard, J. -M. 1987. Field experiments on the relationship between drift and benthic densities of aquatic insects in tropical streams (Ivory Coast). III. Trichoptera. Freshw. Biol. 17:391-404.

Ulmer, G. 1907. Trichopteren. Collections Zoologiques Baron Edm. De Selys Longchamps. Catalogue Systematique et Descriptif. Bruxelles, Hayez. Fasc. 6(2):1-121.

Title: First record of Macrostemum alienum Ulmer 1907 (Trichoptera: Hydropsychidae: Macronematinae) from Ile-Ife, Southwestern Nigeria, West Africa.

Authors: Ogbogu, S.S. and Adu, W.B.

Biota Neotropica, Vol. 6 ( number 3): 2006

http://www.biotaneotropica.org.br/v6n3/pt/ abstract?short-communication+bn00606032006

Date Received 08/01/2005 - Revised 07/08/2006

Accepted 09/01/2006

ISSN 1676-0611 